No. 1, Volume 8 of the Journal of General Microbiology was issued on 4th March 1953

No. 2, Volume 8 of the Journal of General Microbiology was issued on 9th April 1953

Shilo, M. \& Aschner, M. (1953). J. gen. Microbiol. 8, 333-343.

\title{
Factors governing the Toxicity of Cultures containing the Phytoflagellate Prymnesium parvum Carter
}

\author{
By M. SHILO (SHELUBSKY) \\ Department of Microbiological Chemistry, Hebrew University, Hadassah \\ Medical School, Jerusalem, Israel, \\ AND M. ASCHNER \\ Department of Bacteriology, Hebrew University, Jerusalem, Israel
}

SUMMARY: Methods for the laboratory maintenance and purification of cultures of Prymnesium parvum are detailed. The upper limit of temperature for the growth of the organism is $30^{\circ}$. Light exerts an augmenting effect on the production of the toxin by Pr. parvum. Rapid and economical procedures for the bioassay of the toxin are based on the use of Gambusia minnows or tadpoles. Cell-free centrifugates of the cultures contain heat-labile toxic material which is non-diffusible through cellophan, sensitive to oxidizing agents, and reversibly inactivated by mild acidity. The toxin is rapidly inactivated by ubiquitous bacterial species (Bacillus subtilis and Proteus vulgaris). Charcoals, clays and calcium sulphate are efficient adsorbents of the toxic material. The concentration levels of toxin in cultures of Prymnesium parvum appear to reflect a dynamic equilibrium between toxin destruction and production; a similar equilibrium may prevail in nature.

A phytoflagellate toxin was first implicated in an occurrence of mass mortality among fish in Holland by Liebert \& Deerns (1920). Subsequent study of a similar occurrence in Denmark by Otterstroem \& Steeman-Nielsen (1939) identified the responsible organism as Prymnesium parvum Carter, and confirmed that the toxic effect was caused by an extracellular thermolabile toxin. Reich \& Aschner (1947) described the widespread occurrence of this organism in Israel and proposed measures for its control in fishponds.

The present communication describes methods for the maintenance and purification of laboratory cultures of Prymnesium spp. and procedures for the bioassay of the toxin. An analysis of the effects of certain environmental factors on the production and persistence of the toxin in pond water has been attempted. The experiments show the extracellular occurrence of the prymnesium toxin and suggest that it may be a protein.

\section{EXPERIMENTAL}

\section{Bioassay of the toxin of Prymnesium parvum}

Estimations of toxin content of culture fluids and of pond water were made by using Gambusia minnows or tadpoles of Rana or Bufo as the test organism. These species were readily available and could be handled in relatively small volumes of fluid. The tests are carried out as follows. For tadpole tests, five animals are immersed in $5 \mathrm{ml}$. volumes in $15 \mathrm{~mm}$. diam. test-tubes. Cell-free centrifugates of the toxic samples are used for the assay. The dilution medium was sodium chloride solution $(\mathbf{0} \cdot \mathbf{1 6} \%), 9$ volumes + Sorensen's phosphate 
buffer $\mathrm{pH} 8,1$ volume, the mixture being adjusted to final $\mathrm{pH}$ value of $\mathbf{7 \cdot 5}-8 \cdot 5$; temperature of test $15-25^{\circ}$. Bacterial contamination was prevented with streptomycin (1 mg./ml.). Assays were based on direct determinations of the minimum lethal dose or on observations of the time of onset of toxic reactions, particularly the loss of equilibrium sense in minnows (equilibriumloss time), or of tail curvature in tadpoles (see PI. 1). As the Gambusia minnow is the more sensitive test organism, it was preferred for work with dilute toxin. The response is, however, observed sooner in the tadpole, and this is therefore the preferable species for rapid assay work.

A prymnesium toxin unit (T.U.) is defined as the minimum amount of toxin $/ 20 \mathrm{ml}$. which causes death of Gambusia minnows within $12 \mathrm{hr}$. in standard test conditions, specified for the Gambusia test as two minnows about $1.5 \mathrm{~cm}$. long immersed together in $20 \mathrm{ml}$. test fluid in a $50 \mathrm{ml}$. beaker $40 \mathrm{~mm}$. diameter. It should be noted that 1 T.U. in the standard volume of $20 \mathrm{ml}$. will kill more than the two Gambusia minnows, but twofold dilution of the fluid renders it non-toxic even to one minnow. The response observed in these conditions appears to depend on the toxin concentration rather than on the absolute amount of toxin present.

The relationship between toxin concentration and the equilibrium-loss time in minnows is shown in Fig. 1. The relationship between the minimum lethal concentration (M.L.C.) and the equilibrium-loss time was constant in all the toxin solutions tested. The equilibrium-loss time decreased as the amount of toxin increased above 1 T.U., and approached a constant (15-30 min.) at 5 T.U. $/ 20 \mathrm{ml}$. or more. Above 2 T.U. $/ 20 \mathrm{ml}$., the plot of the reciprocal of toxicity against the equilibrium-loss time deviates only slightly from a straight line. The loss of equilibrium sense was always followed by the death of the Gambusia. The minimal lethal concentration and the minimal concentration causing the loss of the equilibrium sense are therefore identical. Titrations of the equilibrium-loss time could be converted into T.U. by reference to Fig. 1 . It is apparent that whereas direct determination of M.L.c. could only be completed in $24 \mathrm{hr}$., the observations of equilibrium-loss time afford reliable estimates of toxin concentration within $1 \mathrm{hr}$., the assay becoming increasingly sensitive and accurate as the equilibrium-loss time is allowed to increase beyond $1 \mathrm{hr}$.

The relationship of toxin concentration to time of showing tail curvature (curvature-time) in tadpoles is illustrated in Fig. 2. It is similar in general to that of equilibrium-loss time in Gambusia minnows to toxin concentration (cf. Fig. 1). The tadpole requires more toxin for a visible response, the minimum effective dose being $2 \cdot 2$ T.U. $/ 20 \mathrm{ml}$. As the toxin dose increased the curvaturetime decreased at a decreasing rate and became constant above 50 T.U./20 ml. at a value near $8 \mathrm{~min}$. Curvature-times of 15-30 min. were satisfactory for assay. Curvature response was always followed by the death of the tadpole.

The ratio of the minimum dose causing equilibrium loss to that causing tail curvature response was found to be $2 \cdot 2$ within a fluctuation limit of $10 \%$ in ten water samples from different natural sources. The constancy of ratio suggests that the equilibrium-loss in minnows and curvature response in 
tadpoles are caused by the same toxin, though in this connexion it should be noted that tail curvature in tadpoles can also be elicited by other agents, e.g. D.D.T. (Schreiman \& Rugh, 1949).

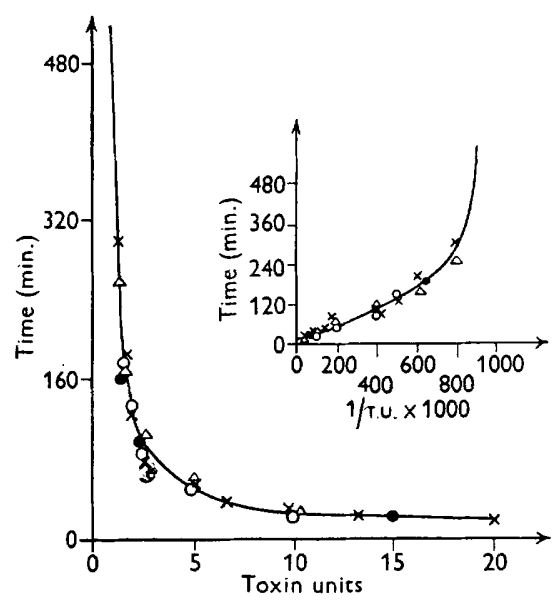

Fig. 1

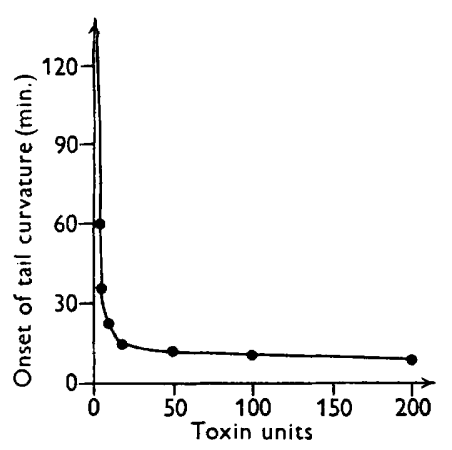

Fig. 2

Fig. 1. The relationship between toxin concentration and equilibrium-loss time in Gambusia minnows. Toxicity expressed in toxin units (т.U.)/20 ml. of immersion fluid was determined on graded dilutions of cell-free supernatant fluid of toxic prymnesium cultures. Different symbols represent different batches of toxin.

Fig. 2. The relationship between toxin concentration and tail-curvature time in tadpoles. Toxicity tests were made on young Rana tadpoles. Values plotted represent averaged results of experiments with three toxin preparations. Toxin concentrations were converted to standard T.U. by multiplying the tadpole M.L.c. by the factor $2 \cdot 2$ which relates M.L.C. of minnows to that of tadpoles.

\section{Preparation and storage of cell-free toxin solution}

Liebert \& Deerns (1920) showed that toxic water samples subjected to moderate heating may kill fish even though they no longer contain viable phytoflagellates. Otterstroem \& Nielsen (1939) observed that centrifugation of pond water which resulted in a marked diminution of the flagellate concentration did not render the sample non-toxic and suggested that the toxic principle was extracellular. We found that centrifugation at 10,000 r.p.m. for $15 \mathrm{~min}$. in the Servall angle centrifuge gives a cell-free toxin solution. Benzylpenicillin (500-1000 units $/ \mathrm{ml}$.) plus streptomycin $(0 \cdot 5-1 \cdot 0 \mathrm{mg} \cdot / \mathrm{ml}$.) were added to the toxin solutions to prevent bacterial contamination. This cell-free fluid was as toxic as the original cell suspension and could be stored without marked loss of potency in the refrigerator for a period up to 4 weeks.

\section{Microscopical examination of cultures and determination of population densities}

Living organisms were examined in hanging-drop preparations. For permanent preparations, the hanging drop was placed above iodine crystals, fixation being effected by the iodine vapour. The drops were spread out in 
a thin film, dried, and stained for 1 sec. with undiluted Gram's gentian violet.

The suspensions of organisms were counted in a blood counting chamber which contained a small crystal of iodine in the overflow channel. Fixation with iodine preserved the shape of the rather fragile organisms of Pr.parvum better than other fixatives and made it easy to see the third flagellum, which is somewhat difficult to observe in life and which serves as the principal identifying characteristic of the genus.

\section{Maintenance and purification of cultures}

We used water from brackish fishponds in which the concentration of $\boldsymbol{P r}$. parvum varied from $\mathbf{1 0 , 0 0 0}$ to 5000,000 organisms $/ \mathrm{ml}$. Samples were kept at winter room temperature $\left(12-15^{\circ}\right)$ in the laboratory in a northern window or under a $40 \mathrm{~W}$. daylight lamp. Tall cylindrical glass vessels or test tubes halffilled with medium served as culture vessels. Under these conditions the Pr. parvum multiplied and maintained toxicity for long periods, whereas most of the other algae present usually diminished in number until they could no longer be detected by direct microscopic examination. The persistence of low number of algal forms which were not Prymnesium spp. was demonstrated by adding ammonium sulphate in a concentration lytic to Prymnesium spp. or by heating at $35^{\circ}$ for short periods; this was followed by reappearance of other algal species in the cultures.

The medium was pond water of suitable salinity (about $1000 \mathrm{mg}$. $\mathrm{Cl} / \mathrm{l}$.) which had been allowed to undergo self-purification in the dark, Chu's medium (1942), or sea water which had been diluted 1:10 with tap water. The pH values of these media ranged from $7 \cdot 5$ to $9 \cdot 0$. The prymnesium cultures were grown with massive transfer ( 1 volume of inoculum in $2-5$ volumes of medium) at intervals of 2-4 weeks.

Typical growth is summarized in Table 1. Marked increases in the final prymnesium counts followed the incorporation of fish peptone or egg yolk (Table 2). Routine addition of these supplements was held to be undesirable, however, since they also promoted the growth of non-prymnesium members of the population, especially bacteria. Excessive proliferation of bacteria may lead to disappearance of Pr. parvum from the culture.

Temperatures higher than $30^{\circ}$ were markedly inhibitory; exposure to $35^{\circ}$ for intervals as short as $5 \mathrm{~min}$. was sufficient to cause death. Caution was thus required when cultures were exposed to direct sunlight, and cooling of the cultures was necessary. $P r$. parvum survives at temperatures as low as $2^{\circ}$ for many days. The seasonal fluctuations of Pr. parvum density in ponds throughout Israel correspond broadly with these temperature requirements of the organism, the density rising markedly in winter and falling almost to nil at the beginning of summer when the pond temperatures approach $30^{\circ}$.

Adequate illumination of the cultures was important for cell proliferation and maintenance of culture toxicity. Light affected toxicity more quickly than cell number. The experiment in Table 3 shows the specific effect of light on the toxicity as distinct from its effect on cell proliferation. In cultures transferred in the laboratory under standard conditions there are generally 
Table 1. The multiplication of Prymnesium parvum in different nutrient media

Inoculation of the nutrient media was by massive transfer of Prymnesium parvum after two previous transfers through the same media. The inoculum in these experiments was 1/3-1/10 of the total volume of the medium. Cultures were kept in 1 l. cylindrical containers at room temperature in diffuse northern light (1000-1500 lux).

\begin{tabular}{|c|c|c|c|c|c|}
\hline \multirow[b]{2}{*}{ Medium } & \multicolumn{5}{|c|}{$\begin{array}{l}\text { Prymnesium counts (organisms/ } / \mu 1 \text {.) on } \\
\text { successive days }\end{array}$} \\
\hline & 0 & 1 & 2 & 4 & 8 \\
\hline \multicolumn{6}{|l|}{ Pond water:* } \\
\hline Culture 1 & 120 & 280 & 500 & 970 & 1050 \\
\hline Culture 2 & 130 & 340 & 1070 & 1090 & 1660 \\
\hline Culture 3 & 370 & 830 & - & 1360 & $\ldots$ \\
\hline \multicolumn{6}{|c|}{$\begin{array}{l}\text { Tap water containing } 7 \% \text { sea } \\
\text { water: }\end{array}$} \\
\hline Culture 4 & 230 & $\ldots$ & $\mathbf{2 5 0}$ & 410 & 500 \\
\hline Culture 5 & 600 & 一 & - & 1200 & 1500 \\
\hline \multicolumn{6}{|c|}{$\begin{array}{l}\text { Chu medium no. } 10 \dagger \text { containing } \\
7 \% \text { sea water: }\end{array}$} \\
\hline Culture 4 & 230 & 180 & 580 & 900 & 1400 \\
\hline Culture 3 & 300 & 660 & $\longrightarrow$ & 1200 & - \\
\hline
\end{tabular}

Table 2. Influence of nutrients added to pond water on prymnesium counts

Pond-water cultures containing equilibrium populations of prymnesium were divided into similar glass containers and kept at room temperature in northern diffuse light with nutrient supplements as described below.

\begin{tabular}{|c|c|c|c|c|}
\hline \multirow[b]{2}{*}{ Nutrient supplement } & \multicolumn{4}{|c|}{ Period of cultivation (days) } \\
\hline & 0 & 4 & 14 & 18 \\
\hline & \multicolumn{4}{|c|}{ Prymnesium counts (organisms $/ \mu 1$} \\
\hline Egg yolk: & 390 & 500 & 400 & 530 \\
\hline 1,100 & 350 & 650 & 2,940 & 4,000 \\
\hline 5,000 & 340 & 480 & 1,230 & 1,700 \\
\hline $1: 10,000$ & 350 & 410 & 700 & 800 \\
\hline $1: 50,000$ & 390 & 280 & 400 & 420 \\
\hline $1: 100,000$ & 360 & 370 & 250 & 480 \\
\hline Fish peptone:* 0 & 820 & 860 & 900 & 一 \\
\hline $1: 500$ & 820 & 2050 & 2,300 & - \\
\hline 1,000 & 920 & 1910 & 2,470 & $\longrightarrow$ \\
\hline 5,000 & 740 & 一 & 900 & - \\
\hline $1: 10,000$ & 610 & $\ldots$ & 690 & - \\
\hline $\mathbf{0}$ & 120 & 140 & 150 & 一 \\
\hline $1: \quad 1,000$ & 100 & 480 & 1,250 & - \\
\hline
\end{tabular}

* As prepared by Snieszko, Griffin \& Friddle (1950). 
1 to 4 T.U. $/ 10^{6}$ organisms, the concentration of the toxin $2-6$ days after transfer being $c .1$ T.U./ml. of culture.

The cultures also contained protozoa and bacteria. The relationship between the different species is not well understood. As is shown in Table 4, Pr. parvum possess a relatively high degree of resistance to several antibiotics, and

Table 3. Influence of light on cell density and toxicity of prymnesium cultures

In this experiment a sample of non-toxic pond water was dispensed into three cylindrical vessels which were placed at room temperature under different lighting conditions as indicated below. Toxicity was tested with Gambusia minnows. Illumination was measured with the help of an exposure-meter and expresses average intensity in each condition at noon.

\begin{tabular}{|c|c|c|c|c|c|c|c|c|c|c|}
\hline \multirow[b]{3}{*}{$\begin{array}{c}\text { Illumination } \\
\text { of } \\
\text { culture }\end{array}$} & & \multicolumn{9}{|c|}{ Age of culture } \\
\hline & & \multicolumn{3}{|c|}{$\underbrace{0 \mathrm{hr} .}$} & \multicolumn{3}{|c|}{$24 \mathrm{hr}}$. & \multicolumn{3}{|c|}{$72 \mathrm{hr}}$. \\
\hline & $\begin{array}{c}\text { Relative } \\
\text { light } \\
\text { intensity }\end{array}$ & $\begin{array}{c}\text { Count of } \\
\text { prymnesium } \\
\underset{\mu \mathrm{l} . \text { ) }}{\text { (organism/ }}\end{array}$ & $\begin{array}{c}\text { Toxicity } \\
\text { (units } / 20 \mathrm{ml} .)^{2}\end{array}$ & $\begin{array}{l}\text { T. } . / 10^{6} \\
\text { cells }\end{array}$ & $\begin{array}{c}\text { Count of } \\
\text { prymnesium } \\
\text { (organism/ } \\
\mu 1 . \text { ) }\end{array}$ & $\begin{array}{c}\text { Toxicity } \\
\text { (units } / 20 \mathrm{ml} \text {.) }\end{array}$ & $\begin{array}{l}\text { T.ण. } / 10^{6} \\
\text { cells }\end{array}$ & $\begin{array}{c}\text { Count of } \\
\text { prymnesium } \\
\text { (organism/ } \\
\mu \text { l.) }\end{array}$ & $\begin{array}{c}\text { Toxicity } \\
\text { (units } / 20 \mathrm{ml} \text { ) }\end{array}$ & $\begin{array}{l}\text { T. } . / 10^{6} \\
\text { cells }\end{array}$ \\
\hline $\begin{array}{l}\text { Diffuse day- } \\
\text { light }\end{array}$ & 12 & 250 & $<1$ & $<0 \cdot 2$ & 260 & 5 & 1 & 420 & 10 & $1 \cdot 2$ \\
\hline $\begin{array}{l}\text { Fluorescent } \\
\text { light* }\end{array}$ & 9 & 250 & $<1$ & $<0 \cdot 2$ & 350 & $<1$ & $<0 \cdot 3$ & 240 & 4 & $0 \cdot 8$ \\
\hline $\begin{array}{l}\text { Laboratory } \\
\text { interior }\end{array}$ & 7 & 250 & $<1$ & $\begin{array}{l}<0.2 \\
0 \mathrm{~W} . \text { lan }\end{array}$ & $\begin{array}{c}260 \\
\text { np operated } f\end{array}$ & $\begin{array}{c}<1 \\
\text { for } 12 \mathrm{hr} . / \text { day }\end{array}$ & $<0 \cdot 2$ & 140 & $<1$ & $<0 \cdot 3$ \\
\hline
\end{tabular}

Table 4. Survival of prymnesium in cultures containing antibacterial concentrations of selected antibiotics

Pond-water cultures with specified antibiotic were kept in northern diffuse light at room temperatures $\left(\mathbf{2 2}^{\circ}\right)$. The prymnesium counts are indicated as follows:

$++++500-1000 / \mu 1 . ;+++250-500 / \mu 1 . ;++50-250 / \mu 1 . ;+10-50 / \mu 1 . ;-<10 / \mu 1$.

\begin{tabular}{|c|c|c|c|c|c|c|c|c|c|c|}
\hline \multirow{3}{*}{$\begin{array}{l}\text { Antibiotic added } \\
\text { Penicillin } \mathrm{G}^{*}\end{array}$} & \multirow{3}{*}{$\begin{array}{c}\text { Time of } \\
\text { assay after } \\
\text { addition of } \\
\text { antibiotic } \\
\text { (days) } \\
1 \\
3 \\
7\end{array}$} & \multicolumn{9}{|c|}{ Concentration of antibiotic (mg./ml.) } \\
\hline & & $6 \cdot 5$ & $3 \cdot 3$ & $2 \cdot 0$ & $1 \cdot 0$ & $\begin{array}{c}0.5 \\
\text { ival of pry }\end{array}$ & $\begin{array}{c}0.25 \\
\text { nnesium }\end{array}$ & $0 \cdot 1$ & 0.05 & 0.01 \\
\hline & & $\begin{array}{c}++ \\
- \\
-\end{array}$ & $\begin{array}{l}+++t \\
+++t \\
+++t\end{array}$ & $\begin{array}{l}++++ \\
++++ \\
+++t\end{array}$ & $\begin{array}{l}++++ \\
++++ \\
++++\end{array}$ & $\begin{array}{l}++++ \\
++++ \\
+++t\end{array}$ & $\begin{array}{l}++++ \\
++++ \\
++++\end{array}$ & $\begin{array}{l}++++ \\
+++t \\
+++t\end{array}$ & $\begin{array}{l}++++ \\
++++ \\
++++\end{array}$ & $\begin{array}{l}++++ \\
+++t \\
++++\end{array}$ \\
\hline Streptomycin $\dagger$ & $\begin{array}{l}1 \\
3 \\
7\end{array}$ & : & : & $\begin{array}{c}+++ \\
+\end{array}$ & $\begin{array}{l}++++ \\
++++ \\
++++\end{array}$ & $\begin{array}{l}++++ \\
++++ \\
++++\end{array}$ & $\begin{array}{l}++++ \\
++++ \\
++++\end{array}$ & $\begin{array}{l}++++ \\
++++ \\
++++\end{array}$ & $\begin{array}{l}++++ \\
++++ \\
++++\end{array}$ & $\begin{array}{l}++++ \\
++++ \\
+++t\end{array}$ \\
\hline Terramycin & $\begin{array}{l}1 \\
3 \\
7\end{array}$ & $\dot{.}$ & $\dot{.}$ & $\begin{array}{l}- \\
-\end{array}$ & $\begin{array}{l}- \\
-\end{array}$ & $\begin{array}{l}- \\
-\end{array}$ & $\begin{array}{l}+ \\
- \\
-\end{array}$ & $\begin{array}{l}+ \\
+ \\
-\end{array}$ & $\begin{array}{c}++ \\
+ \\
+\end{array}$ & $\begin{array}{c}++++ \\
+++ \\
++\end{array}$ \\
\hline Chloramphenicol & $\begin{array}{l}1 \\
3 \\
7\end{array}$ & : & $\dot{.}$ & $\overline{-}$ & $\begin{array}{l}- \\
- \\
-\end{array}$ & $\begin{array}{l}- \\
- \\
-\end{array}$ & $\begin{array}{c}++ \\
- \\
-\end{array}$ & $\begin{array}{c}++ \\
- \\
-\end{array}$ & $\begin{array}{c}++ \\
++ \\
+\end{array}$ & $\begin{array}{l}++++ \\
++++ \\
++++\end{array}$ \\
\hline Aureomycin & $\begin{array}{l}1 \\
3 \\
7\end{array}$ & : & : & $\begin{array}{l}- \\
z\end{array}$ & $\begin{array}{l}- \\
-\end{array}$ & $\underline{-}$ & $\begin{array}{l}- \\
- \\
-\end{array}$ & $\begin{array}{l}- \\
-\end{array}$ & $\begin{array}{c}++ \\
- \\
-\end{array}$ & $\begin{array}{c}+++ \\
++ \\
++\end{array}$ \\
\hline
\end{tabular}

advantage may be taken of this to purify cultures. The Pr. parvum survived and even multiplied in the presence of bactericidal concentration of streptomycin and penicillin. When $\mathbf{0} \cdot \mathbf{1} \mathrm{ml}$. samples of culture fluid containing these antibiotics were inoculated into nutrient broth, brain and heart infusion, and into glucose agar media, they often failed to show bacterial growth within 24-48 hr. after the addition of the antibiotics. Cultures of Pr. parvum which 
were bacteria-free by this criterion were carried in an antibiotic-free medium for several transfers. Such cultures tended to die after 2-3 weeks. The causes of the decline are being studied.

Population density of Prymnesium parvum in pond-water samples and laboratory cultures; relationship to the toxicity of the culture fluids

Counts of Pr. parvum and toxicity assays of pond-water samples taken from selected locations are shown in Table 5; the counts are arranged in order of size.

Table 5. Population of Prymnesium spp. and toxicity of fishponds

Location and serial number
of pond

\begin{tabular}{|c|c|c|}
\hline Date of sample & $\begin{array}{l}\text { Prymnesium } \\
\text { count } \\
\text { (organisms/ } / \text { l.) }\end{array}$ & $\begin{array}{c}\text { Toxicity } \\
\text { (units } / 20 \mathrm{ml} \text {.) }\end{array}$ \\
\hline 25. xi. 46 & 1080 & 1.0 \\
\hline 28. $x . \quad 46$ & 960 & $1 \cdot 0$ \\
\hline 10. xii. 46 & 870 & $1 \cdot 0$ \\
\hline 15. xii. 46 & 600 & $1 \cdot 0^{*}$ \\
\hline 11. v. 49 & 550 & $1 \cdot 0$ \\
\hline 17. v. 49 & 400 & $1 \cdot 0^{*}$ \\
\hline 20. xi. 50 & 300 & $1 \cdot 0$ \\
\hline 26. xi. 50 & 300 & $1 \cdot 0^{*}$ \\
\hline 6. vi. 52 & 240 & $10-20$ \\
\hline 26. viii. 48 & 60 & $1 \cdot 0^{*}$ \\
\hline 1. iii. 47 & 50 & $1 \cdot 0^{*}$ \\
\hline
\end{tabular}

$\mathbf{1} \cdot 0^{*}$ indicates toxin concentration which killed carp, i.e. $=1 \cdot 3 \mathrm{~T}$.U.

As Reich \& Aschner (1947) showed there is no simple relationship between the $P r$. parvum count and the toxicity of the pond-water sample. In fact, very high prymnesium counts are sometimes associated with absence of toxicity (e.g. $7 \times 10^{6}$ organisms $/ \mathrm{ml}$.; <0.05 T.U. $/ \mathrm{ml}$.). On the other hand, several highly toxic samples of pond water gave very low prymnesium counts $\left(5 \times 10^{4}\right.$ organisms $/ \mathrm{ml}$; $>0.5$ T.U. $/ \mathrm{ml}$. $)$. The wide variation of the toxicity: count ratio might be due to the occurrence of variants of Pr.parvum or to differential effects of environmental factors on the production and destruction of the toxin. The notion that the low toxicity:count ratios are characteristic for non-toxigenic variants could be ruled out by the observation that pond-water samples of low or undetectable toxicity and a high count for prymnesium regularly yield highly toxic cultures when maintained in the laboratory under standard conditions for 2-3 days. During this interval the increase in the flagellate population is less than twofold, and it seems unlikely that a process of natural selection favouring a toxigenic variant is responsible for the increase in toxicity.

When the population density of laboratory cultures was increased by growth-promoting supplements to numbers in excess of $5 \times 10^{6}$ flagellates $/ \mathrm{ml}$, an inverse relationship between cell count and toxicity was sometimes observed. Dilution of such dense cultures with sea water or pond water rapidly reestablished the normal toxicity: count ratio. An example of such an experiment is given in Table 6. Cultures of high cell count have a deep brown colour 
and considerable turbidity. It remains to be ascertained to what extent the decrease in toxicity which is associated with excessive cell proliferation may be due to the inadequate illumination of the interior of the culture.

\section{Table 6. Effect of dilution on toxicity of dense prymnesium cultures}

A static culture of Prymnesium parvum which had been fortified with a soil supplement and contained $7 \cdot 3 \times 10^{8}$ prymnesium organisms $/ \mathrm{ml}$. was diluted in the proportions shown below with 1 : 10 strength sea water and held for $24 \mathrm{hr}$. in cylindrical vessels at room temperature under a $40 \mathrm{~W}$. daylight lamp.

\begin{tabular}{|c|c|c|c|c|}
\hline \multirow{2}{*}{$\begin{array}{c}\text { Dilution of } \\
\text { culture with } \\
1: 10 \text { strength } \\
\text { sea water }\end{array}$} & \multicolumn{2}{|c|}{ Organisms $\times 10^{6} / \mathrm{ml}$. } & \multicolumn{2}{|c|}{ T.U. $/ 20 \mathrm{ml}}$. \\
\hline & $0 \mathrm{hr}$. & $24 \mathrm{hr}$. & $0 \mathrm{hr}$. & $24 \mathrm{hr}$. \\
\hline $1: 0$ & $7 \cdot 30$ & $7 \cdot 30$ & $<1 \cdot 0$ & $<1$ \\
\hline $1: 4$ & $1 \cdot 46$ & $1 \cdot 66$ & $<1 \cdot 0$ & $2 \cdot 5$ \\
\hline $1: 0$ & 0.73 & 0.90 & $<1 \cdot 0$ & $5 \cdot 0$ \\
\hline
\end{tabular}

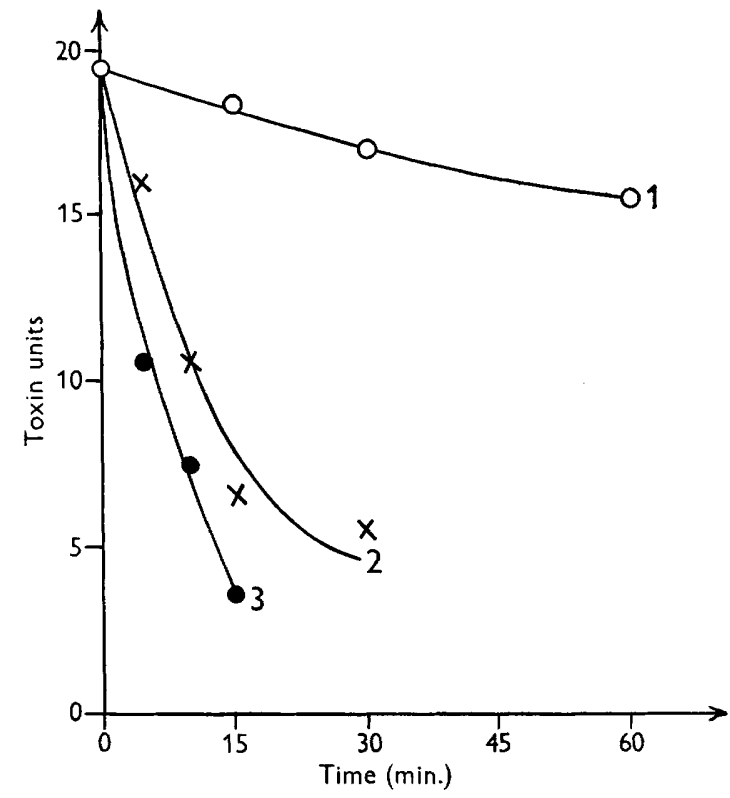

Fig. 3. The effect of temperature on prymnesium toxin. The toxicity expressed in T.U. $/ 20 \mathrm{ml}$. was tested with Gambusia. Curves 1,2 and 3 show effects of exposure to 62,80 and $97^{\circ}$ respectively.

Observations on general properties of the toxin of Prymnesium parvum cultures

Effect of temperature. At 97 and at $80^{\circ}$, the toxicity of the culture supernatant fluid declined rapidly; at $62^{\circ}$ the decline was relatively slow. Thermal inactivation became progressively slower as the concentration of the toxin fell (Fig. 3). At room temperature and at $4^{\circ}$ there was no detectable loss of toxicity for at least 7 days, provided that bacterial growth did not occur and oxidation was prevented. 
Diffusibility. Solutions of toxin in cellophan tubing showed no significant fall in titre when suspended in frequently renewed distilled water or in isotonic sodium chloride solution $(0 \cdot 16 \%)$ for $12-24 \mathrm{hr}$. at $4^{\circ}$.

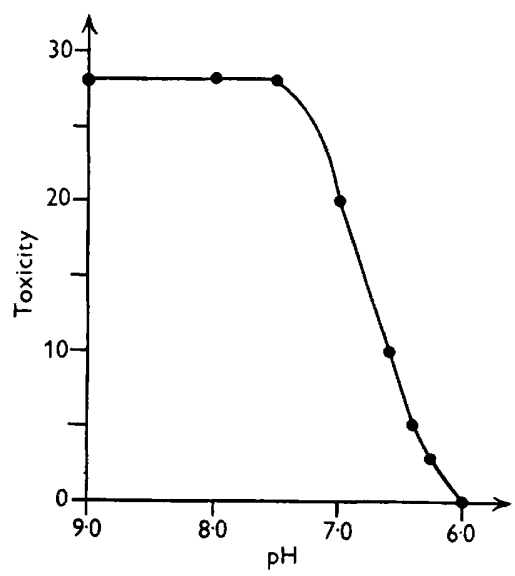

Fig. 4

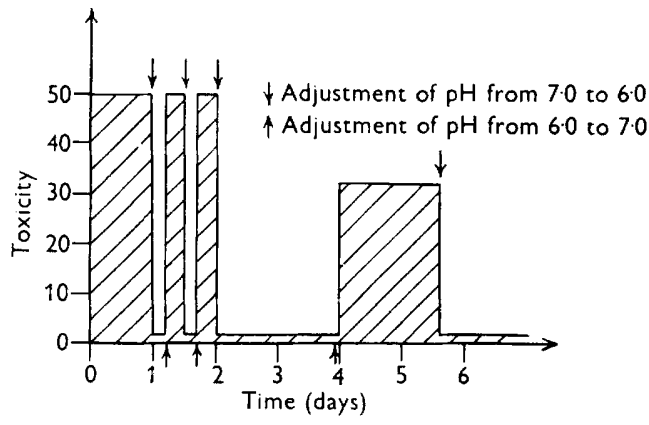

Fig. 5

Fig. 4. Influence of $\mathrm{pH}$ on activity of toxin. The toxin solution contained 28 T.U. $/ 20 \mathrm{mI}$. The $\mathrm{pH}$ was adjusted with phosphate buffer $0.02 \mathrm{~m}$ in the range $\mathrm{pH} 6 \cdot 0-8.0$ and with borate buffer (Clark) at a final concentration of $1: 10$ in the range $\mathbf{p H ~} 7 \cdot 8-9 \cdot 0$. The toxicity was measured on Gambusia $1 \mathrm{hr}$. after the adjustment of the $\mathrm{pH}$ of the toxin solution. Buffer solutions containing $10 \%$ sea water of the same $\mathrm{pH}$ and concentration were used for dilution.

Fig. 5. Reversible inactivation of toxin at acid $\mathrm{pH}$ values. Toxicity is expressed as the reciprocal of the equilibrium-loss time in minutes. $\mathrm{pH}$ was adjusted as indicated by addition of $0.5 \mathrm{~N}$-hydrochloric acid or sodium hydroxide.

Effect of $\mathrm{pH}$ value. The influence of the $\mathrm{pH}$ value on toxicity is illustrated in Fig. 4. Toxicity was independent of $\mathrm{pH}$ value within the range $7 \cdot 5-9 \cdot 0$. The toxicity decreased rapidly at $\mathrm{pH}$ values below $7 \cdot 5$, and was zero at $\mathrm{pH} 6 \cdot \mathbf{0}$. At moderate acidities, the inactivating effect of hydrogen ion was almost completely reversible for at least several days (Fig. 5). This behaviour resembles that of different enzyme proteins. Assuming that the variation of the $\mathrm{pH}$ value is modifying the nature of the toxin, it would follow that the toxin possibly possesses a functional group of $\mathrm{pK}$ near 6-7. However, it should not be overlooked that the variation of the $\mathrm{pH}$ value might also be affecting the susceptibility of the test animal.

Oxidizing agents. Toxicity declined when oxygen was bubbled through a solution of toxin; air produced the same result though somewhat more slowly. Potassium permanganate $\left(2 \times 10^{-4} \mathrm{M}\right)$ or sodium hypochlorite $(2.0$ p.p.m.) added to culture supernatant fluid containing $0.5 \mathrm{~T} . \mathrm{U} . / \mathrm{ml}$. immediately destroyed toxicity.

Adsorbents. A wide variety of adsorbents removed the toxic material from culture supernatant fluid. At room temperature, the toxicity of $50 \mathrm{ml}$. containing 2.5 T.U. was completely removed within $5 \mathrm{~min}$. by $2-5 \mathrm{~g}$. of kaolin, Norit A (acid washed), activated charcoal, or calcium sulphate $\left(\mathrm{CaSO}_{4} \cdot \mathbf{2} \mathrm{H}_{2} \mathrm{O}\right)$. 
Under the same conditions, Decalso, calcium carbonate, kieselguhr, Fuller's earth and activated alumina (Eimer \& Amend) removed little or no toxin. Highly toxic cultures were rapidly detoxified by stirring with pond-bottom soils. When such cultures are then allowed to remain in contact with the soil, they continue non-toxic for periods up to a fortnight in conditions which are otherwise favourable to toxin production.

Destruction of toxin by micro-organisms. A destructive action of microorganisms on the toxin was suggested by the observation that the maintenance of the toxicity of stored toxin solution at all temperatures compatible with bacterial growth was conditional on the addition of suitable antibiotics to the toxin sample. Washed suspensions of Proteus vulgaris and of Bacillus subtilis decreased the potency of prymnesium toxic culture supernatant fluid by at least $50 \%$ in $1 \mathrm{hr}$., whereas Bacterium coli was almost without effect under the same conditions.

\section{DISCUSSION}

The prymnesium toxin appears to be a substance of high molecular weight with some of the properties of a protein. It is readily differentiated from other algal toxins, notably those found in marine dinoflagellates (Sommer et al. 1948 $a, b$; Connell \& Gross, 1950) and in Microcystis (Prescott, 1948; Ashworth \& Mason, 1946; Shelubsky, 1951) which are intracellular constituents of cells and not excreted into the medium. Some explanation can now be offered of the puzzling lack of correlation between the population density of Prymnesium parvum and the toxicity of the pond water. The pronounced lability of the prymnesium toxin to oxidizing agents, its ready adsorption by bottom soil and its rapid destruction by micro-organisms may explain non-toxic pond waters. Light, by augmenting toxin production, works in the opposite direction, and is probably one of many factors which regulate toxin production in nature. The concentration of toxin observed represents, therefore, a dynamic equilibrium between production and destruction. The dramatic increases in toxicity which may be observed in fish ponds with stable prymnesium populations can thus represent either the withdrawal of a toxin-removing agency or an enhancement of a factor concerned in toxin production.

This work was supported in part by a grant from the Fish Breeders Association of Israel. The co-operation of the Department for Fisheries of the Ministry of Agriculture of the Government of Israel is also gratefully acknowledged. We are grateful to Mrs Miriam Shilo for her contributions to the experiments on the purification of the prymnesium cultures, to Mr S. Sarig for help in the field work, and to Dr S. Hestrin for valuable suggestions.

\section{REFERENCES}

Ashworth, C. T. \& Mason, M. F. (1946). Observations on the pathological changes produced by a toxic substance in the blue-green algae (Microcystis aeruginosa). Amer. J. Path. $22,369$.

CHU, S. P. (1942). The influence of the mineral composition of the medium on the growth of planktonic algae. I. Methods and culture media. J. Ecol. 30, 284.

Connell, C. H. \& Gross, J. B. (1950). Mass mortality of fish associated with the protozoan Gonyaulax in the Gulf of Mexico. Science, 112, 359. 

Journal of General Microbiology, Vol. 8, No. 3

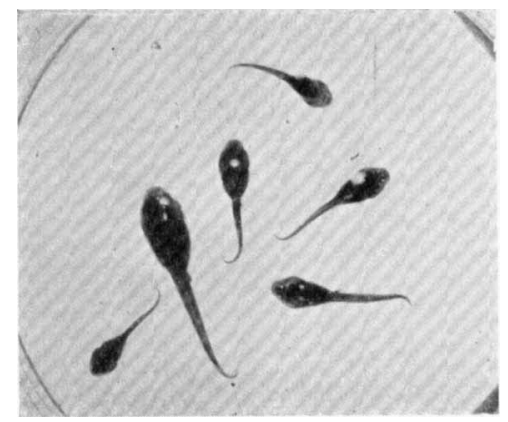

Fig. 1

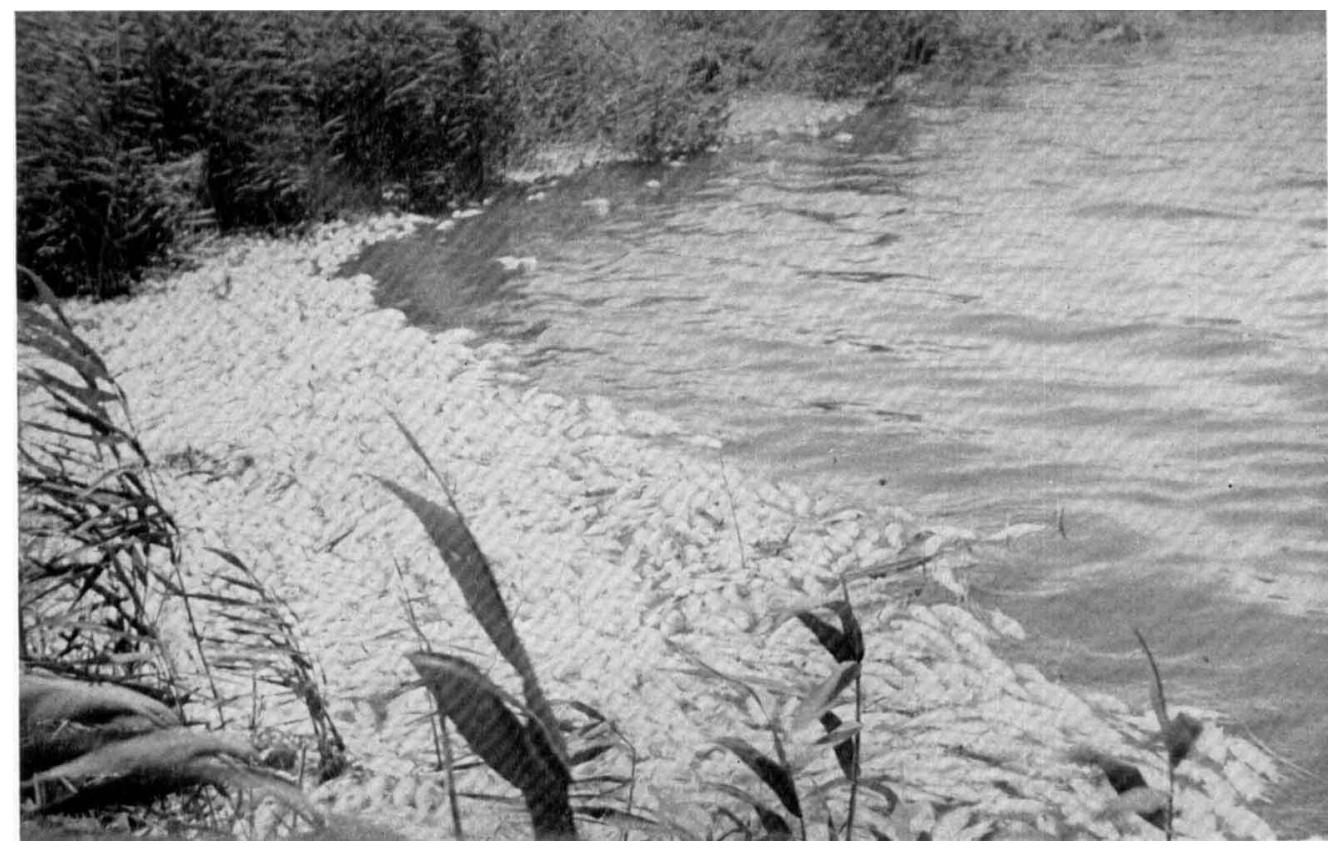

Fig. 2

M. Shilo \& M. Aschner-The exotoxin of prym Parvum. Plate 1 
Liebert, F. \& Deerns, W. M. (1920). Onderzoek naar de Oorzaak van een Vischsterfte in den polder Workumer-Nieuwland, Nabij Workum. Verh. Rijksinst. VisschOnderz. 1, 81.

Otterstroem, C. V. \& Steemann Nielsen, E. (1939). Two cases of extensive mortality in fishes caused by the flagellate Prymnesium parrum Carter. Rep. Danish biol. Sta. 44, 5.

Prescotr, G. W. (1948). Objectionable algae, with reference to the killing of fish and other animals. Hydrobiologia, 1, 1.

Reich, K. \& Aschner, M. (1947). Mass development and control of the phytoflagellate Prymnesium parvum in fishponds in Palestine. Palest. J. Bot. Jerusalem, $4,14$.

Schreiman, E. \& Rugh, R. (1949). Effect of D.D.T. on functional development of larvae of Rana pipiens and Fundulus heteroclitus. Proc. Soc. exp. Biol., N.Y., 70,431 .

Shelubsky, M. (1951). Observations on the properties of a toxin produced by Microcystis. Proc. Ont. Ass. theor. appl. Limnol. 11, 362.

Snieszko, S. F., Griffin, P. J. \& Friddle, S. B. (1950). A new bacterium (Haemophilus piscium. n.sp.) from ulcer disease of trout. J. Bact. 59, 699.

Sommer, H., Mounier, R. P., Riegel, B., Stranger, D. W., Mold, J. D., Wikholm, P. M. \& Krralis, E. S. (1948a). Paralytic shellfish poison. I. Occurrence and concentration by ion exchange. J. Amer. chem. Soc. 70, 1015.

Sommer, H., Riegel, B., Stranger, D. W., Mold, J. D., Wikholm, D. M. \& McCaughey, M. B. (1948b). Paralytic shellfish poison. II. Purification by chromatography. J. Amer. chem. Soc. 70, 1019.

\section{EXPLANATION OF PLATE}

Fig. 1. Tadpoles of Rana sp. after 15 min. in toxin solution. Typical curvature of the tail is the first visible effect of the intoxication.

Fig. 2. Mass-mortality of fish in a carp-breeding pond caused by toxin of Prymnesium parvum.

(Received 5 August 1952) 